\title{
Erratum to: Climate change projections over three metropolitan regions in Southeast Brazil using the non-hydrostatic Eta regional climate model at $5-\mathrm{km}$ resolution
}

\author{
Andre Lyra ${ }^{1}$ (D) - Priscila Tavares $^{1} \cdot$ Sin Chan Chou ${ }^{1} \cdot$ Gustavo Sueiro $^{1} \cdot$ \\ Claudine Dereczynski ${ }^{2} \cdot$ Marcely Sondermann $^{2} \cdot$ Adan Silva $^{1} \cdot$ José Marengo $^{3}$. \\ Angélica Giarolla ${ }^{1}$
}

Published online: 3 April 2017

(C) Springer-Verlag Wien 2017

\section{Erratum to: Theor Appl Climatol DOI 10.1007/s00704-017-2067-z}

In Lyra et al. (2017), regarding the sentence in page 4, section 2.4, first column, second paragraph:

"The MRRJ is located in the state of Rio de Janeiro. This area of approximately 5 million $\mathrm{km}^{2}$ with a population of almost 12 million people (CEPERJ 2010) is the second largest urban agglomeration in Brazil and the twentieth largest in the world (IBGE 2010). The
MRSP is approximately 8 million $\mathrm{km}^{2}$ with a population of approximately 21 million people (IBGE 2010)."

The sentence should read:

"The MRRJ is located in the state of Rio de Janeiro. This area of approximately 5 thousand $\mathrm{km}^{2}$ with a population of almost 12 million people (CEPERJ 2010) is the second largest urban agglomeration in Brazil and the twentieth largest in the world (IBGE 2010). The MRSP is approximately 8 thousand $\mathrm{km}^{2}$ with a population of approximately 21 million people (IBGE 2010).”

The online version of the original article can be found at http://dx.doi. org/10.1007/s00704-017-2067-z

Andre Lyra

andre.lyra@cptec.inpe.br

1 National Institute for Space Research (INPE), Rod Pres Dutra km 39, Cachoeira Paulista, SP, Brazil

2 Federal University of Rio de Janeiro (UFRJ), Av Athos da Silveira Ramos 274, Ilha do Fundão, Cidade Universitária, Rio de Janeiro, RJ, Brazil

3 National Centre for Monitoring and Early Warning of Natural Disasters (CEMADEN), Rod Pres Dutra km 39, Cachoeira Paulista, SP, Brazil 